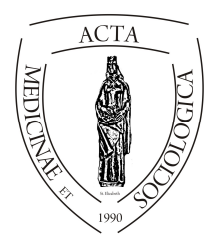

Acta Medicinae et

Sociologica (2020)

Vol. 11., Különszám. (43-54)

doi:

\title{
Az utánpótlás korú labdarúgók sérüléseinek jellemzői
}

\author{
Szalánczi Zoltán ${ }^{1}$, Takács Dániel ${ }^{2}$ \\ ${ }^{1} \mathrm{PhD}$ hallgató, Debreceni Egyetem, Gazdaságtudományi Kar, Sportgazdasági és -menedzsment Inté- \\ zet, Debrecen \\ 2 Gyógytornász, Debreceni Labdarúgó Akadémia, Debrecen
}

INFO

Szalánczi Zoltán

szalanczi.zoltan@gmail.com

Keywords:

sport injury, professional

sport, youth sport

\section{ABSTRACT}

\begin{abstract}
In the modern individual- and team sports the technical and tactical abilities reached their limit. To gain competitive advantage, the only choices are in the improvement of the physical and mental abilities. This advantage is gained by pushing the limitations of the human capacity, which can be an indicator for injury. In our research we will deal with the sports injuries, with in the most commonly occurrent injuries in soccer. In the first half of the article we will define the most common injuries for adult players based on international publications, and in the second part we will compare these results with the incidence in the youth soccer players from our research. With the build-up of the academy system, and with the increase of the physical requirements of the modern football, the youth players are exposed to a bigger load. In our research we will try to define the effect, and the incidence of certain injuries on the grounds of this huge load given in the growth-phase to the youth players compared to data and type experienced with adult players to find analogy or difference between them.
\end{abstract}

Kulcsszavak:

sportsérülés, professzionális sport, utánpótlás sport
Absztrakt: Napjainkra a modern egyéni- és csapatsportban a technikai és taktika képességek elérték a határukat. A versenyelőny megszerzésének egyetlen lehetősége a fizikaiés mentális fejlesztésben rejlik. Ez az előny azonban a teljesítőképesség határainak folyamatos feszegetésével jár, mely gyakran sérülések indikátora lehet. Kutatásunkban a sportés azon belül a labdarúgásban leggyakrabban elöforduló sérülésekkel kívánunk foglalkozni. A publikáció első felében a felnőttekre jellemző sérüléstípusokat határozzuk meg a nemzetközi szakirodalom alapján, majd ezeket hasonlítjuk össze az utánpótláskorúaknál előfordulókkal egyéni kutatásunk alapján. Az akadémiai rendszer kiépülésével és a modern futball fizikális követelményeinek növekedésével a 
fiatal labdarúgók is egyre nagyobb terhelésnek vannak kitéve. A kutatásban arra keressük a választ, hogy a még fejlödés alatt álló játékosok esetében ennek a nagy terhelésnek vannak-e olyan következményei, melyek bizonyos sérüléstípus számának emelkedésével járnak, vagy megegyezik-e a felnőtteknél tapasztalt előfordulási adatokkal és jelleggel.

Ez a tanulmány a EFOP-3.6.2-16-2017-00003 Sport- Rekreációs és Egészséggazdasági Kooperációs Kutatóhálózat létrehozása projekt támogatásával készült.

\section{Szakirodalmi áttekintés A sérülések definíciója}

Sokáig nem került meghatározásra az, hogy mi is számít sportsérülésnek. Hiányzott egy egységes definíció, mely alapján el lehetett volna határolni őket előfordulásuk és típusuk alapján. Fuller, Ekstrand és munkatársaik (2006) megfogalmazásában minden olyan sérülést sportsérülésnek kell tekinteni, mely a sportolás közben vagy amiatt alakult ki. Ez az elmélet a futball területéről indult, így kutatásom szempontjából releváns lehet. A kutatók meghatároztak különböző osztályokat is a sérülések csoportosításában, melyek alkalmazása függött attól, hogy ezek orvosi ellátást igényeltek-e, illetve mekkora ideig nem állt a játékos a csapat rendelkezésére.

Fuller, Ekstrand és munkatársaik (2006) alapján tehát a sérülés egy olyan bántalom, mely labdarúgó mérkőzés vagy edzés következtében alakul ki, függetlenül attól, hogy orvosi ellátással vagy a futball tevékenységekből való kimaradással jár. Az a sérülés, amely orvosi kezeléssel jár, az „orvosi ellátást igénylő” sérülésnek minősül, amely pedig azzal jár, hogy a jövőben a játékos képtelen teljes értékü edzésmunkát végezni vagy meccsen szerepelni, az „,időveszteséggel járó” sérülésnek tekintendő.

Az „orvosi ellátást igénylő” sérülés kategória azt jelenti, hogy orvosi ismeretekkel bíró személy beavatkozására van szükség ahhoz, hogy a játékos szervezetét viszszaállítsuk a korábbi állapotba. Az „,időveszteséggel” járó sérülés pedig azt jelenti, hogy a játékos a sérülés után közvetlenül vagy attól időben elszakadva később nem tud szerepelni egy vagy több alkalommal. Fontos azonban megemlíteni, hogy az egyén fájdalomtürő képessége, az orvosi támogatás és ellátás minősége jelentősen befolyásolhatja a sérülések előfordulásának és súlyosságának megítélését. A tanulmányban fontos szempont továbbá az újrasérülések regisztrációja, mint új sérüléseké, hiszen a játékos gyógyulttá nyilvánítása után bekövetkezendő sérülések kiújulása minden esetben a pályán jelentkező hatásoknak köszönhető. Fuller, Ekstrand és munkatársaik (2006) megfogalmazásában azok az újrasérülések, melyek ugyanolyan típusúak és ugyanott jelentkeznek, mint a korábbi sérülés a játékos teljes felépülése után. Három kategóriába sorolja ezeket. Az első a korai kiújulású kategória, mely két hónappal a sérülésböl való visszatérés után jelentkezik. A második csoport a késői kiújulású, amely a felépüléstől számított második és tizenkettedik hónap időszakára tehető, illetve a harmadik, mely egy évvel később jelentkezik, az a késleltetett kiújulású típus. 
A sportsérülésekkel kapcsolatban további kutatásokat vizsgálva egyéb különbségeket fedezhetünk fel. Bahr és Holme (2003) tanulmányából kiderül, hogy a minden hatodik orvosi ellátást igénylő sérülés sportolás közben, vagy sportolás miatt alakul ki. Azonban a vizsgálat kitért arra is, hogy ezek az adatok sportáganként jelentős eltéréseket mutatnak. Például a kézilabda játékosok átlagosan minden 10. mérkőzésen szereznek kisebb-nagyobb sérülést, míg a röplabdázóknál ez a szám lényegesen magasabb. Ök átlagosan minden 100. mérkőzésen sérülnek meg (Fuller, Ekstrand és munkatársaik, 2006). A sérülések súlyosságának tekintetében egy angol vizsgálat kimutatta, hogy a teljes kockázati mutató a labdarúgók között a legmagasabb. Majd' ezerszerese a kiemelten magas sérülési kockázatokkal rendelkező foglalkozásokénak (Drawer, Fuller és munkatársaik 2002). Egy frissebb kutatásban Jain, Liu és munkatársaik (2014) kimutatták 8 holland első osztályú csapat vizsgálatán keresztül a 2009/2010-es szezonban, hogy 217 játékos összesen 286 sérülést szenvedett, mely a játékosok 62,7\%-át érintette. A sérülések átlagos előfordulása 6,2 volt 1000 játékórára vetítve. Ebbe beletartoztak az edzések és meccsek is. Ezekből a vizsgálati eredményekböl láthatjuk, hogy a sérülés egy olyan komoly faktor az élsportban, melynek nemcsak a sportszakmai sikerekben, hanem a gazdasági müködés eredményességben is nagy szerepe van.

\section{Sportsérülések kiváltó okai}

A sérülésekkel kapcsolatos kockázati tényezők két csoportba sorolhatók. Az első a belső, sportolóhoz köthető, míg a második pedig a külső, környezeti kockázati tényezők (van Mechelen, Hlobil, Kemper, 1992). Ugyanakkor ezeket a rizikófaktorokat meg lehet határozni változtatható és állandó tényezőkként is. Az állandók közé tartozik a nem, a kor, és egyéb genetikusan meghatározott szempontok. A befolyásolható faktorokhoz tartozik az edzés intenzitása, az ingerek sürüsége, vagy akár az edzés helyszíni, közvetlen körülményei is ide sorolhatók. Azonban nem elegendő csupán ezeket a kockázati tényezőket vizsgálni, hiszen a sérülés előfordulása leginkább egy mechanizmus „végterméke”. Más szóval megfogalmazva a sérülés egy komplex folyamat, melyben a különböző kockázati tényezők és események együttes interakciója jön létre, mely hatásoknak csak töredékét vagyunk képesek észlelni (Bahr, Holme, 2003). Ennek következtében a sérülések kórtana igényel egy olyan dinamikus modellt, mely tartalmazza a sportsérülések többtényezős hatásmechanizmusát, valamint számol azzal a ténnyel, hogy a sérülések egy folyamat eredményeként realizálódnak. Ezt a modellt legjobban az alábbi ábra szemlélteti Meeuwisse, Tyramen és munkatársaik (2007) meghatározása alapján. 


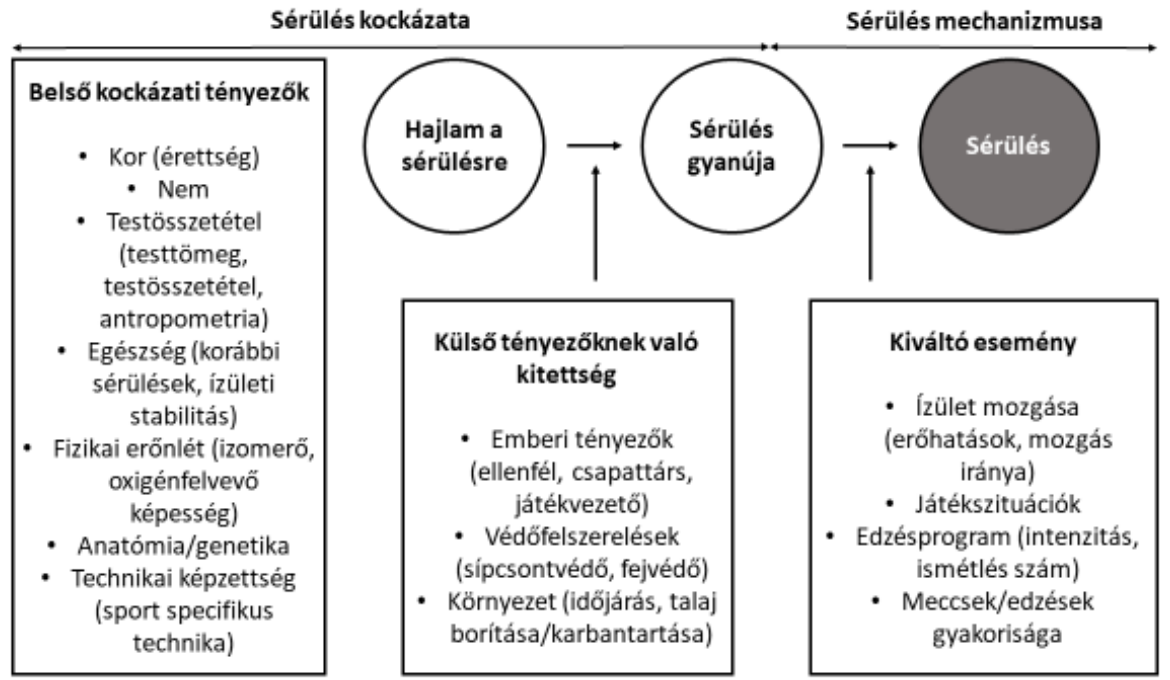

Forrás: Saját szerkesztés Meeuwisse (2007) alapján

1. ábra. Többtényezős modell a sérülések kialakulásában

Az 1. ábrán látható folyamatot vizsgálva láthatjuk, hogy mely tényezők komplex hatása játszhat közre a sérülések előfordulásában. A kutatók meghatározták, melyek azok a belső kockázati faktorok, melyek elöre jelezhetnek egy esetleges sérülést, de önmagukban nem elegendőek azt előidézni. A modellben megjelennek a külső tényezőket befolyásoló elemek, melyek megléte vagy hiánya a sérülés kialakulásában döntő szerepet játszhatnak. Mind a két esetben csak kockázati tényezőkről beszéltünk, melyeknek a megjelenése vagy megléte önmagukban nem elegendők arra, hogy a sérülést közvetlenül indikálják, azonban a jelenlétükkel már felmerül a sérülés gyanúja, mely egy adott szituációban a sérülés kialakulásával jár majd. Meeuwisse Tyramen és munkatársaik (2007) meghatározásában egy kiváltó esemény, az utolsó mozzanat a sérülés kialakulásában, ami általában közvetlenül a sérült testrészhez köthető.

\section{A labdarúgásban előforduló sérülések nemzetközi szakirodalom alapján}

2009-ben az UEFA kérésére Ekstrand és Waldén (2009) elkészítettek egy tanulmányt, melyben a 2001-2008-ig tartó időszakban 23 labdarúgócsapatot vizsgáltak a sérülések előfordulásának tekintetében. Ahhoz, hogy a tanulmány releváns információkat tartalmazzon, a saját ranglistájuk legjobb 50 csapatából választották ki a kutatás alanyait. A tanulmány 566.000 óra (475.000 óra edzés, 91.000 óra mérkőzés) sporttevékenységet vizsgált, amely alatt 4483 sérülés következett be. Az átlag játékos 34 mérkőzésen és 162 edzésen szerepelt egy szezonban. Ennek a megoszlása 
időben az 1. táblázatban látható, melyen megfigyelhető, hogy egy átlagos játékosnál 213 óra edzés, és 41 mérkőzésen eltöltött óra realizálódott. Ebből kimutatható, hogy minden sporttal eltöltött 1000 órára 8 sérülés jut. A sérülések helyszíne szerinti megoszlása azt mutatja, hogy 2546 (57\%) mérkőzésen, míg 1937 (43\%) edzésen történt. Fontos kiemelni, hogy ez a kutatás a sport legmagasabb szintjén folyt, ahol kizárólag professzionális sportolók találhatóak.

\begin{tabular}{|c|c|c|c|c|c|c|c|c|}
\hline \multirow{2}{*}{$\begin{array}{l}\text { Tevékenység } \\
\text { típusa }\end{array}$} & \multirow{2}{*}{$\begin{array}{l}\text { Minden } \\
\text { szezon } \\
\text { átlaga } \\
\text { (szórás) }\end{array}$} & \multicolumn{7}{|c|}{ Szezonok } \\
\hline & & $2001 / 02$ & $2002 / 03$ & $2003 / 04$ & $2004 / 05$ & $2005 / 06$ & $2006 / 07$ & $2007 / 08$ \\
\hline $\begin{array}{c}\text { Mérkőzések } \\
\text { száma }\end{array}$ & 34 (17) & $36(16)$ & $39(16)$ & $33(17)$ & $35(16)$ & $33(17)$ & $32(17)$ & $33(17)$ \\
\hline Edzések száma & $162(53)$ & $\begin{array}{l}174 \\
(53)\end{array}$ & $\begin{array}{l}181 \\
(45)\end{array}$ & $\begin{array}{l}151 \\
(47) \\
\end{array}$ & $\begin{array}{l}171 \\
(46)\end{array}$ & $\begin{array}{l}156 \\
(55)\end{array}$ & $\begin{array}{l}155 \\
(56)\end{array}$ & $\begin{array}{l}160 \\
(52)\end{array}$ \\
\hline $\begin{array}{l}\text { Sporttevékenység } \\
\text { (óra) }\end{array}$ & $254(85)$ & $\begin{array}{l}262 \\
(80)\end{array}$ & $\begin{array}{l}290 \\
(74)\end{array}$ & $\begin{array}{l}243 \\
(80)\end{array}$ & $\begin{array}{l}273 \\
(79)\end{array}$ & $\begin{array}{l}247 \\
(89)\end{array}$ & $\begin{array}{l}245 \\
(90)\end{array}$ & $\begin{array}{l}246 \\
(83)\end{array}$ \\
\hline $\begin{array}{l}\text { Mérkőzés } \\
\text { (óra) }\end{array}$ & $41(23)$ & $43(22)$ & $47(23)$ & $40(24)$ & $44(24)$ & $40(23)$ & $38(24)$ & $40(24)$ \\
\hline $\begin{array}{l}\text { Edzés } \\
\text { (óra) }\end{array}$ & $213(71)$ & $\begin{array}{l}219 \\
(66) \\
\end{array}$ & $\begin{array}{l}243 \\
(64)\end{array}$ & $\begin{array}{l}203 \\
(67)\end{array}$ & $\begin{array}{l}229 \\
(65) \\
\end{array}$ & $\begin{array}{l}207 \\
(75)\end{array}$ & $\begin{array}{l}207 \\
(75) \\
\end{array}$ & $\begin{array}{l}206 \\
(68)\end{array}$ \\
\hline
\end{tabular}

Forrás: Saját szerkesztés Ekstrand (2009) alapján

1. táblázat. A sérülések előfordulása tevékenységek szerint (szórás)

\begin{tabular}{|c|c|c|c|c|c|}
\hline Sérülés típusa & Összes sérülés & $1-3$ nap & $4-7$ nap & 8 -28 nap & > 28 nap \\
\hline Törés & 160 & 7 & 9 & 59 & 85 \\
\hline Egyéb csontsérülés & 26 & 5 & 1 & 6 & 14 \\
\hline Ficam, részleges ficam & 50 & 5 & 4 & 24 & 17 \\
\hline Rándulás, szalagsérülés & 828 & 123 & 197 & 334 & 174 \\
\hline Porcsérülés & 124 & 3 & 7 & 41 & 73 \\
\hline Izomsérülés, húzódás & 1581 & 212 & 397 & 765 & 207 \\
\hline Ínszalagsérülés & 327 & 95 & 71 & 101 & 60 \\
\hline Véraláfutás, zúzódás & 744 & 306 & 282 & 141 & 15 \\
\hline Horzsolás & 7 & 3 & 3 & 1 & 0 \\
\hline Seb & 31 & 10 & 11 & 10 & 0 \\
\hline Agyrázkódás & 34 & 5 & 14 & 14 & 1 \\
\hline Idegsérülés & 29 & 7 & 3 & 14 & 5 \\
\hline Gyulladás & 158 & 55 & 36 & 55 & 12 \\
\hline Túlterheléses panaszok & 285 & 110 & 99 & 59 & 17 \\
\hline Egyéb & 91 & 23 & 27 & 24 & 17 \\
\hline Összesen & 4483 & 971 & 1164 & 1651 & 697 \\
\hline
\end{tabular}

Forrás: Saját szerkesztés Ekstrand és Waldén (2009) alapján

2. táblázat. A sérülések típusai és az általuk realizált kihagyás 
A bemutatott kutatás alapján megállapítható, hogy egy sportoló évente átlagosan legalább két sérülést szenvedett. Ez egy 25-ös kerettel rendelkező labdarúgó csapatra vetítve 50 sérülést jelent a csapat számára. Ezeknek a sérüléseknek a típusát és számát Ekstrand és Waldén (2009) nyomán a 2. táblázat mutatja be. Kiemeltük, hogy melyek azok a jellegzetes sérülések, melyek a legtöbbször fordulnak elö a professzionális labdarúgók között. A labdarúgás speciális jellemzőit tekintve láthatjuk, hogy jórészt az izom- és szalagsérülések azok, amelyekkel számolni kell a sportolóknak. A leggyakrabban előforduló sérülés a súlyosság tekintetében pedig a 8-28 napig terjedő izomhúzódások csoportja.

Ekstrand és Waldén (2009) megvizsgálták, hogy melyek azok a sérülések, amelyek a leggyakrabban fordulnak elő a labdarúgásban, és ezek hatására hány napig nem áll a csapat rendelkezésére a játékos. A leggyakoribb sérülés a combizomhúzódás volt, mely a sérülések $17 \%$-át tette ki, míg a közelítő sérülés a második helyen, már csak 9\%-át jelentette a sérüléseknek, mely után a bokaficam és MCL sérülés következett előfordulási gyakoriságban. Ezek a megoszlási adatok a 3. táblázatban láthatóak.

\begin{tabular}{|c|c|c|}
\hline Sérülés típusa & Előfordulások száma & $\%$ \\
\hline Combizomhúzódás & 743 & 17 \\
\hline Közelítő húzódás & 399 & 9 \\
\hline Bokaficam & 318 & 7 \\
\hline Belső oldalszalag sérülés & 220 & 5 \\
\hline
\end{tabular}

Forrás: Saját szerkesztés Ekstrand (2009) alapján

3. táblázat. A leggyakrabban előforduló sérülések

\section{Módszer és minta}

Magyarországon hozzávetőlegesen 250 ezer igazolt labdarúgót tartanak számon, melynek közel fele utánpótlás korú. Az elmúlt években az állami támogatásoknak köszönhetően számos futball akadémia jött létre országszerte, mely akadémiák a nemzetközi sztenderdnek megfelelnek. Az akadémiákon folyó szakmai munka monitorozása mellé elengedhetetlen lenne a játékosok egészségügyi állapotának, sérüléseinek is a nyomon követése. Sajnos, ezen a téren nincs egységes módszer a különböző események dokumentálására, éppen ezért kevés tanulmány, kutatás olvasható ebben a témában. Nemzetközi viszonylatban számos publikáció taglalja az utánpótláskorú futballsérülések előfordulásának gyakoriságát adva ezzel az összehasonlítás lehetőségét. Ilyen vizsgálat a Koutures és Gregory (2010) által elvégzett vizsgálat az utánpótlás labdarúgásban elöforduló sérülések, valamint a Deehan, Bell és McCaskey (2007) által megalkotott összefoglalás a futball akadémiákon tapasztalható vázizomzatot érintő sérülésekről, vagy Pfirrmann, Herbst és Ingelfinger (2016) által összeállított beszámoló a felnőtt professzionális szinten sportoló és elit akadémiákon foglalkozatott játékosok sérüléseinek előfordulásáról. 
Jelen kutatás célja az utánpótláskorú labdarúgók sérüléseinek dokumentálása egy saját fejlesztésü sérülésregiszter segítségével, a Debreceni Labdarúgó Akadémián. A sérülésregiszter tudományos hátterét a Nemzetközi Labdarúgó Szövetség Orvosi és Kutató (F-MARC) részlegének ajánlásait alapul véve készítettük. A dokumentálás megkönynyítésére, az Orchard-féle kódrendszer magyar verzióját/fordítását alkalmaztuk.

A sérüléseket a 2013/14 futballszezon alatt regisztráltuk az alábbi csapatoknál: U14, U15, U16, U17, U18, U21. Ez 2013/14-ben 134 játékost jelentett, a szezon 10 hónapig tartott kétszer 5 hónapos (július közepe - december közepe / január közepe - június közepe) lebontásban. Egy szezonban 38 mérkőzést játszottak a csapatok, míg az edzések száma átlagosan 200 volt. Egy mérkőzés hossza U14 és U15-os korosztálynál kétszer 40 percböl, U16-U17-U18-U21-os korosztálynál kétszer 45 percből állt. Az edzések hossza hozzávetőlegesen másfél óra volt.

Futballsérülésnek tekintettünk minden olyan fizikai/mozgásszervi panaszt, amit a sportoló futballmérkőzésen vagy edzésen szenvedett el, és ennek következményében a sportoló az edzés/mérkőzés felfüggesztése mellett egészségügyi ellátásra szorult.

Dokumentálás során feljegyeztük az alábbi információkat: a sérülés jellege (akut, túlterheléses, újrasérülés), a sérülés típusa (pl: húzódás, ficam, szakadás), volt-e külső erőbehatás (kontakt, non-kontakt), a sportoló posztját (támadó, középpályás, védő, kapus). Továbbá regisztráltuk a kihagyott napok számát, azt, hogy mikor sérült (edzés, mérkőzés) a sportoló. Az adatokat az Akadémia gyógytornásza, illetve orvosa rögzítette a sérülést követő első találkozáskor. A diagnózis felállítása is ennek a két szakembernek a feladata volt, mely a kutatástól függetlenül munkaköri leírásukban rögzítésre került. Kutatásunkban az Akadémia orvosa egyéb szerepet nem vállalt. A sportoló mindaddig sérültnek minősült, amíg az egészségügyi team a csapathoz való visszatérést nem engedélyezte. A betegség miatt kihagyott napok száma nem került be a végső eredmények közé. A játékosok személyes- és ezen belül az egészségügyi adatainak kezelését az akadémia egy általános, minden rendszerébe integrált, játékossal aláíratott adatkezelési engedély útján kezeli, mely anonim módon az adatok kutatási céllal történő felhasználását is lehetővé teszi. A kiskorúaknál ez szülöi engedéllyel került bővítésre.

\section{Eredmények}

A vizsgált szezon alatt 233 sérülést regisztráltunk, a sérülések közül 85,4\% az alsó végtagot érintette. A sérülések megoszlása mechanizmus szerint: 70,82\% $(n=165)$ non-kontakt, 29,18\% (n=68) kontakt.

A sérült képletek a 4. táblázatban kerültek meghatározásra, melyek közül $65 \mathrm{db}$ izomsérülést tapasztaltunk, ami 27,89\%-a teljes mintának, valamint ebből $51 \mathrm{db}$ a húzódás, ami 21,88\%-át teszi ki az összes sérülésnek. Továbbá $57 \mathrm{db}$ bokasérülés jegyeztünk fel, ami 24,45\%-a az összes sérülés számának. Ebböl szalagsérülés 43db, ami 18,45\%-a az összesnek, továbbá 14db egyéb sérülés, ami törés, rúgás stb. Mindemelett $54 \mathrm{db}$ térdsérülés is bekövetkezett, ami a 23,17\% az egészre vetítve, és ennek a fele, azaz $27 \mathrm{db}$, ami a térdízület meghatározható képleteit érintette (szalag, meniscus, ín), 27-szer pedig „térdfájdalom” fordult elö. Egyéb alsó végtag sérülés (achilles, talp, lábfej, lábszár, sarok) 22 alkalommal fordult elö, ami 9,44\%-a az 
összes sérülésnek, valamint a felső végtag sérülései és a törzs sérülései együtt $15 \mathrm{db}$ ot tettek ki, mely 6,5\%-a az összes előfordulásnak, és a derékpanaszok $20 \mathrm{db}$-os száma 8,5\%-ot jelentett az összes sérülésre vetítve. Ha össze kívánjuk hasonlítani az utánpótlás korú és a felnőtt játékosokat a sérülés típusai szerint, akkor látható, hogy a tendenciák közel hasonlóak. Mindkét korcsoport esetében felfedezhető, hogy az izomsérülések, majd a boka és a térdsérülések a legmeghatározóbb képletek.

\begin{tabular}{|c|c|c|}
\hline Sérült terület & Sérülések száma $(\mathrm{db})$ & Százalékos arány \\
\hline Izom & 65 & 27,89 \\
\hline Boka & 57 & 24,45 \\
\hline Térd & 54 & 23,17 \\
\hline Egyéb alsó végtag sér. & 22 & 9,44 \\
\hline Felső végtag és törzs & 15 & 6,5 \\
\hline Derékpanaszok & 20 & 8,5 \\
\hline Összesen: & 233 & 99,95 \\
\hline
\end{tabular}

Forrás: saját szerkesztés 2019

4. táblázat. Az előfordult sérülések és megoszlásuk

A korosztályok szerinti megoszlást az 5. táblázatot vizsgálva láthatjuk. Az U16-os korosztály volt az, amelyik a legtöbb sérülést elszenvedte, de a nagypályás korosztályok tekintetében az U15-öt kivéve mindenhol elérte legalább a 35-öt a sérülések előfordulása. Ha a nemzetközi szakirodalomban említett 50 sérülést tekintjük alapnak az összehasonlításhoz, akkor láthatjuk, hogy egyetlen korosztály esetében sem érte el ezt a számot az előfordulásuk. Ennek oka valószínüsíthetően a felnőtt labdarúgás támasztotta elvárások (intenzitás, párharcok száma és minősége, nagyobb testsúly és izomtömeg) lehetnek, hiszen az utánpótlás sportban a fiatal labdarúgók fizikális fejlettsége még nem teszi őket alkalmassá, hogy a legmagasabb szinten üzzék ezt a sportot. Azonban a tendenciákból arra lehet következtetni, hogy az U14-es korosztályban, mely a nagypályára lépés időszaka, a nagyobb térhez és a pályán lévő játékosok nagyobb számához, ezáltal a gyorsabb kivitelezésre és több parharchoz való alkalmazkodás nagyobb mennyiségü sérüléssel jár, valamint az U16-os korosztályban megnövelt játékpercek (40-röl 45-re / félidö) olyan kritikus ingert fejtenek ki a játékosra, ami a sérülések előfordulásának a növekedésével is jár.

\begin{tabular}{|c|c|c|}
\hline Korosztály & Sérülések száma $(\mathrm{db})$ & Százalékos arány \\
\hline U14 & 45 & 19,31 \\
\hline U15 & 27 & 11,59 \\
\hline U16 & 49 & 21,03 \\
\hline U17 & 39 & 16,74 \\
\hline U18 & 38 & 16,31 \\
\hline U21 & 35 & 15,02 \\
\hline Összesen: & 233 & 100 \\
\hline
\end{tabular}

Forrás: saját szerkesztés 2019

5. táblázat. A sérülések megoszlása korosztályok szerint 
A poszt szerinti megoszlás tekintetében nincs meghatározó tanulmány, így mindenképpen fontosnak tartom megvizsgálni ezt a kérdést is szakmai szempontból. Jól kirajzolódik az eredményekből a 6. táblázatban, hogy a középpályások és a védők között fordul elő leggyakrabban a sérülés. Ennek ok a pálya közepén helyezkedő játékosok esetében az, hogy a labda jórészt az általuk bejátszott területen van játékban, és a modern futball támasztotta követelményeknek megfelelöen ez a zóna anynyira leszükített a csapatok által, hogy szinte folyamatos párharcok zajlanak itt, már utánpótlás szinten is. A kutatás első feléből ezt megerősíti, hogy a sérülések majd 30\%-a kontakt, ami ezekböl a párharcokból ered.

\begin{tabular}{|c|c|c|}
\hline Poszt & Sérülések száma $(\mathrm{db})$ & Százalékos arány \\
\hline Középpályás & 82 & 35,19 \\
\hline Kapus & 33 & 14,16 \\
\hline Támadó & 46 & 19,74 \\
\hline Védő & 72 & 30,90 \\
\hline Összesen: & 233 & 100 \\
\hline
\end{tabular}

Forrás: saját szerkesztés 2019

6. táblázat. A sérülések megoszlása posztok szerint

A másik nagyobb kategóriát a védők jelentik, akik egyrészt szintén sok párharcra vannak késztetve, másrészt a támadók mélységi indításokkal való megjátszása esetén sokszor álló helyből, vagy lassú mozgásból sprintre vannak kényszerítve, ami a mérkőzés vége felé egy fáradt, vagy esetleg egy nem megfelelően felkészített izomzatnak olyan terhelést ad, ami sok esetben sérülést vált ki. A kapusok sérüléseinek elöfordulása szintén a játék sajátosságát fejezi ki, hiszen az ő esetükben a labdaérintések és a játékba lépések száma töredéke a mezőnyjátékosokénak, azonban a posztspecifikus mozgásaik szintén komoly sérüléssel játhatnak, így ezért 14\% fölötti az érték.

A nemzetközi tanulmányt vizsgálva a felnőtt játékosok nagyobb számban sérültek meg a mérkőzésen, mint edzésen, de ez szintén a képzési feladatok különbségének köszönhetö. A 7. táblázatban felfedezhető, hogy a fiatalok közel azonos számú sérülést tapasztaltak mérkőzésen és edzésen egyaránt, ami arra vezethető vissza, hogy az utánpótlás játékosok az edzésen még minden egyes nap a határaikat feszegetik, illetve olyan terhelést kapnak, ami a fejlödésüket szolgálja és nem a hétvégi eredményességet. A felnőtt profi futballisták számára ezzel szemben már egy heti ritmus kerül kialakításra, ahol a meccs előtti edzéseken már a mérkőzésre való frissesség kialakítása a fő cél, a képzés és a fizikális képességek fejlesztés a felkészülési időszakban véget ér. Számukra a hétvégi eredmény a döntő, míg a fiatalok képzésének az csak egy eleme.

A sérülés jellege vizsgálatunkban a 8. táblázatban került meghatározásra. A nemzetközi tendenciákhoz hasonlóan elsősorban akut sérülések jelentkeznek a sportolóknál, míg a túlterheléses sérülések szintén jelentős hányadát teszik ki az összes feljegyzett esetnek. 


\begin{tabular}{|c|c|c|}
\hline Sérülés előfordulása & Sérülések száma $(\mathrm{db})$ & Százalékos arány \\
\hline Edzésen & 122 & 52,36 \\
\hline Mérkőzésen & 111 & 47,64 \\
\hline Összesen & 233 & 100 \\
\hline
\end{tabular}

Forrás: saját szerkesztés 2019

7. táblázat. A sérülések megoszlása tevékenység szerint

\begin{tabular}{|c|c|c|}
\hline Sérülés jellege & Sérülések száma (db) & Százalékos arány \\
\hline Akut & 159 & 68,24 \\
\hline Túlterheléses & 69 & 29,61 \\
\hline Újrasérülés & 5 & 2,15 \\
\hline Összesen: & 233 & 100 \\
\hline
\end{tabular}

Forrás: saját szerkesztés 2019

8. táblázat. A sérülések megoszlása jellegük szerint

A sérülések következtében realizált kihagyás hasonlóan a felnőttekhez, legnagyobb számban a 8 és 28 nap közötti idöintervallumot érintette. Ez olyan faktor, amit a korkülönbség nem módosít, hiszen a sérülések gyógyulása jórészt hasonló a fiatal és fiatal felnőtt korban is. Az átlagosan kihagyott napok száma az összes sérülésre vetítve 16,43 nap (szórás 7,07), ami megfelel a nemzetközi tanulmányokban szerepelteknek. Az eredményeket a 9. táblázat szemlélteti.

\begin{tabular}{|c|c|c|c|c|c|}
\hline Kihagyott napok száma & $1-3$ nap & 4-7 nap & 8-28 nap & >28 nap & Összesen \\
\hline Sérülések száma & 3 & 60 & 143 & 27 & 233 \\
\hline
\end{tabular}

Forrás: saját szerkesztés 2019

9. táblázat. A sérülések száma a kihagyott napok tekintetében

\begin{tabular}{|c|c|c|}
\hline Képlet & Sérülések száma $(\mathrm{db})$ & Kihagyott napok számának átlaga \\
\hline Izom & 65 & $11,34(6,24)$ \\
\hline Boka & 57 & $16,56(15,89)$ \\
\hline Térd & 54 & $25,64(32,97)$ \\
\hline Egyéb alsó végtag & 22 & $11,31(11,01)$ \\
\hline Felső végtag és törzs & 15 & $24,88(20,82)$ \\
\hline Derékpanaszok & 20 & $9,95(3,70)$ \\
\hline Összesen: & 233 & - \\
\hline
\end{tabular}

Forrás: saját szerkesztés 2019

10. táblázat. A sérülések miatt kihagyott napok átlagos száma (szórás)

Ami a sérülések által átlagosan kihagyott napok számát illeti, a 10. táblázatban szereplő adatok bemutatják, hogy az utánpótlás sportolók mennyi időt töltöttek bizo- 
nyos sérüléstípusok miatt kényszerpihenőn. Az ö esetükben csak a képzési folyamatból való kimaradást vonja magával a sérülés, de a profi labdarúgók esetében ez már nem csak a játékos, hanem a klubja számára is komoly deficitet jelent a kifizetett bérköltségek és elmaradt hasznok tekintetében.

\section{Összefoglalás és következtetések}

A sport fejlődésével a fizikai korlátokat feszegetik a játékosok. Ezzel sajnálatosan együtt jár a sportsérülések jelentőségének növekedése. Kutatásunkban arra kerestem a választ, hogy a felnőtt, professzionális labdarúgásban előforduló sérülésekhez képest az utánpótlás korúaknál milyen tendenciák vannak jelen. A vizsgálatunk alapján megállapítható, hogy a sérülések típusait tekintve hasonló a sérülések megoszlása a fiatalok és felnőttek között. Továbbá meghatározható két olyan korosztály, ahol a nagypályára lépés és a megnövekedett mérkőzés időtartam miatt emelkedik a sérülések száma. Feltártuk, hogy vannak olyan pozíciók a pályán, ahol jelentősen több sérülés fordul elő a futballspecifikus elemek végett. A további vizsgált faktorokból kiderült, hogy meghatározó eltérés tapasztalható a sérülés jellegét tekintve a két korosztály között, hiszen a fiatal sportolók képzési folyamata miatt az ő esetükben lényegesen több sérülés jelentkezik edzéseken, szemben a profi labdarúgókkal, akiknek a mérkőzésen tapasztalt iram és párharcok jelentik a legnagyobb kockázati faktort. A labdarúgásban tapasztalható sérülésekröl összefoglalóan megállapítható, hogy bizonyos területeken jelentős eltérés tapasztalható az utánpótlás- és felnőttkorú játékosoknál.

\section{Felhasznált irodalom}

1. Bahr R., Holme I. (2003): Risk factors for sports injuries: a methodological approach. Br J Sports Med 37 (5): 384-92 DOI: https://doi.org/10.1136/bjsm.37.5.384

2. Bahr, R., Mechelen, W. (2002): Prevention of sports injuries. M. Kjær, M. Krogsgaard, P. Magnusson, L. Engebretsen, H. Roos, T. Takala \& S. L.Y. Woo (eds) Textbook of Sports Medicine. Basic Science and Clinical Aspects of Sports Injury and Physical Activity. pp. 299-314. Blackwell Science, Oxford

3. Deehan D. J., Bell K., McCaskie A. W. (2007): Adolescent musculoskeletal injuries in a football academy The Journal of Bone and Joint Surgery. British volume 89-B:1, 5-8 DOI: https://doi.org/10.1302/0301-620x.89b1.18427

4. Drawer S., Fuller CW. (2002) Evaluating the level of injury in english professional football using a risk based assessment process. Br J Sports Med 36:446-51 DOI: https://doi.org/10.1136/bjsm.36.6.446

5. Ekstrand J., Hagglund M, Waldén M. (2011): Injury incidence and injury patterns in professional football: the UEFA injury study. Br J Sports Med; 45:553-558

6. Fuller CW., Ekstrand J., Junge A., Andersen TE., Bahr R., Dvorak J., Hagglund M., McCrory P., Meeuwisse W. (2006): Consensus statement on injury definitions and data collection procedures in studies of football (soccer) injuries. 
Scand J Med Sci Sports. 16:83-92. DOI: https://doi.org/10.1111/j.16000838.2006.00528.x

7. Jain TK., Liu W., Santos M., Heller D., Hiller C., (2014): Important issues concerning use of the term 'copers' in chronic ankle instability research. J Sports Med Volume 44, Issue 12, pp 1775-1776 DOI: https://doi.org/10.1007/s40279014-0279-2

8. Koutures C. G., Gregory J. (2010): Injuries in Youth Soccer The Council on sports medicine and fitness, 125 (2) 410-414; DOI: https://doi.org/10.1542/peds.2009-3009

9. Meeuwisse W, Tyreman H, Hagel B, Emery C, (2007): A Dynamic Model of Etiology in Sport Injury: The Recursive Nature of Risk and Causation. Clinical Journal of Sport Medicine: May Vol 17 - Issue 3 - p 215-219 DOI: https://doi.org/10.1097/jsm.0b013e3180592a48

10. Pfirrmann D, Herbst M, Ingelfinger P, (2016) Analysis of Injury Incidences in Male Professional Adult and Elite Youth Soccer Players: A Systematic Review. J Athl Train. 51(5):410-424. DOI: https://doi.org/10.4085/1062-6050-51.6.03

11. Van Mechelen W, Hlobil H, Kemper HC. (1992): Incidence, severity, aetiology and prevention of sports injuries. A review of concepts. Sports Med. 14:82-99 DOI: https://doi.org/10.2165/00007256-199214020-00002 